\title{
Graduate Learning Communities: Transforming Educators
}

Sharon Kabes, Southwest Minnesota State University, USA

Dennis Lamb, Southwest Minnesota State University, USA

John Engstrom, Southwest Minnesota State University, USA

\begin{abstract}
Quantitative data collected from graduates of the Southwest Minnesota State University Master of Science in Education program examined the impact of the learning environment, the role of the facilitator, and their professional development. The results showcased the success of the learning community model in facilitating personal and professional growth and transformation. Essential elements of the program include: best practices, learning environment, effective teaching strategies, research-based decision making, scaffolding, peer collaboration, learning community philosophy, professional growth, empowerment, reflective practitioner, inquiry, and transformational leader (change agent). The data collected from student surveys over a five-year period indicated a high level of impact on their empowerment and transformational practices.
\end{abstract}

Keywords: Master's Program, learning environment, professional development, learning communities, facilitation, transformation, research-based decision making, empowerment, reflective practitioner

\section{INTRODUCTION}

\section{The Learning Community Program}

Q) ince 1996, a Masters Learning Community Program delivered at a Midwestern university has been purposefully designed to foster professional growth of educators through the use of inquiry, self analysis, critical reflection, collaborative problem solving, peer review and feedback. Meaningful collaborative experiences engage students in critical examination and dialogue about educational theory and practice. As students build their understanding about teaching and learning, incorporate ideas and processes into their classrooms, and reflect on those experiences with colleagues, transformation of their practice occurs. There is also a corresponding development of teacher leadership.

Collaboration and peer review are essential elements of the program. Collaborative cultures build the confidence teachers need to lead. In collaborative cultures, teachers support instructional improvement by others. They share ideas and build on those ideas, thus creating a new synergy. They evaluate new ideas that focus on student learning (Kohm \& Nance, 2009). Students participate with the same cohort and faculty facilitators over the course of the two year program.

Peer collaboration is essential to the success of the program. One of the primary groups students work with is a heterogeneous cohort that functions as an advisory team. This team functions in dialoguing, peer review and critique of presentations, projects, classroom implementations, portfolios and action research projects and providing support for team members throughout the program. Students also are assigned to homogeneous groups based on teaching levels and assignments. The students work with these groups on exploration of best practices, curriculum development, and teaching ideas. Other groupings include special interest groups where members select a common research topic and jointly complete research and presentations on those topics. In addition to the standard groupings students are involved in random mixed group activities to build broader community and relationships. 
Students are involved in self-analysis through the use of surveys and indicators such as the Adult Learning Styles Survey, Meyers Briggs Indicators, Adult Learning Style Survey, various leadership inventories, and the Adult Multiple Intelligence Inventories. Teaching is analyzed through the use of teacher checklists and videotaped teaching sessions.

According to Norris, Barnett, Basom, \& Yerkes (2002),

Through a series of processes and experiences, in which the learners are exposed to themselves and their values, others and their values, content knowledge, skills, problem solving and problem finding, problem-based learning activities and case, journals, platforms and portfolios, and reflection and research, student travel the path...Students come to understand their own values and reasons for pursuing the course of study. They come to understand their community and how to provide leadership to others in the community. Through interaction with others in the group, they come to understand and clarify their purpose-their own and that of their community. Key to their learning is the direction of facilitative instructors. (P. 129)

Facilitators work to create a safe and positive learning environment using a constructivist approach. The facilitators incorporate a transformational leadership model, and thus, "provide the mechanism by which solutions are transferred into subsequent practice by building the capacity of the individuals and the group" (Cunningham \& Cordeiro, 2009, p. 210). Students are actively engaged in key constructivist components, which include independent learning, inquiry, self reflection, metacognition, collaborative problem solving, community building and peer review. Books, articles, and other resources are carefully selected to develop student understanding of research based theory and strategies. Themes are spiraled throughout the two year program and are explored in increasing depth.

Qualitative and quantitative data have been collected from program participants focusing on the learning environment, role of the facilitators and professional development. A body of data has provided evidence, which identifies the success of the twelve basic elements of the program: best practices, learning environment, effective teaching strategies, research-based decision making, scaffolding, peer collaboration, learning community philosophy, professional growth, empowerment, reflective practitioner, inquiry, and transformational leader (change agent).

\section{Data Collection Process}

To support the theoretical model of transformation, a quantitative analysis was conducted to further examine the impact the learning communities were having on the participants. Data was collected over a period of five years (2005-2009). Of 581 surveys administered, 464 were completed, producing a $79.9 \%$ return rate. Only data from the learning communities facilitated by the authors are included. The surveys collected were three distinct instruments: Professional Development Survey (113 surveys); Facilitator Survey (191 surveys); and Learning Environment Survey (160 surveys), respectively. Summative surveys were collected from 10 different learning communities, involving three different facilitator teams.

Twelve central elements have been directly linked to the survey instruments used. These serve as the premise for programmatic decision-making, as well as quantitative evidence of the program's success. The twelve elements include:

$\begin{array}{ll}- & \text { Best practices } \\ - & \text { Learning environment } \\ \text { - } & \text { Effective teaching strategies } \\ \text { - } & \text { Research-based decision making } \\ \text { - } & \text { Scaffolding } \\ \text { - } & \text { Peer collaboration } \\ \text { - } & \text { Professional growth }\end{array}$


- $\quad$ Empowerment

- Reflective practitioner

- Inquiry

- $\quad$ Transformational leader (change agent)

Educators enrolled in the program range from beginning to 30 year veterans, with the majority falling between the $4-12$ years of experience (See Figure 1).

Figure 1: Years of Teaching Experience of Learning Community Students

\section{Years of Teaching Experience (2005 - 2009) $N=135$}

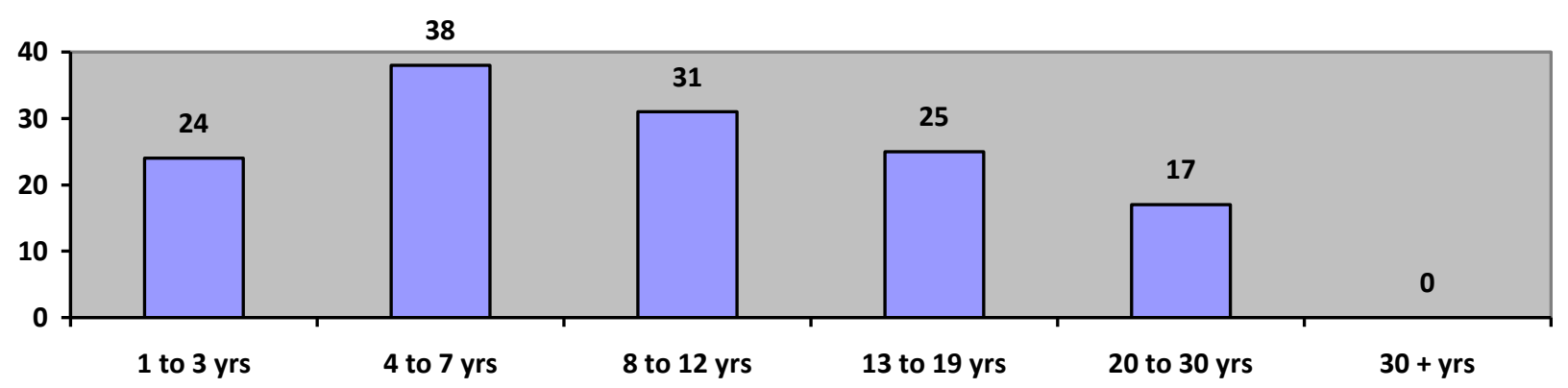

Students who attend the program are drawn from the upper Midwest. Educators from all grade levels enroll in the program, ranging from Early Childhood to College-level instructors (See Figure 2).

Figure 2: Grade Level Teaching Assignment at Time of Enrollment

Grade Level Teaching Assignment (2005 - 2009) N = 128

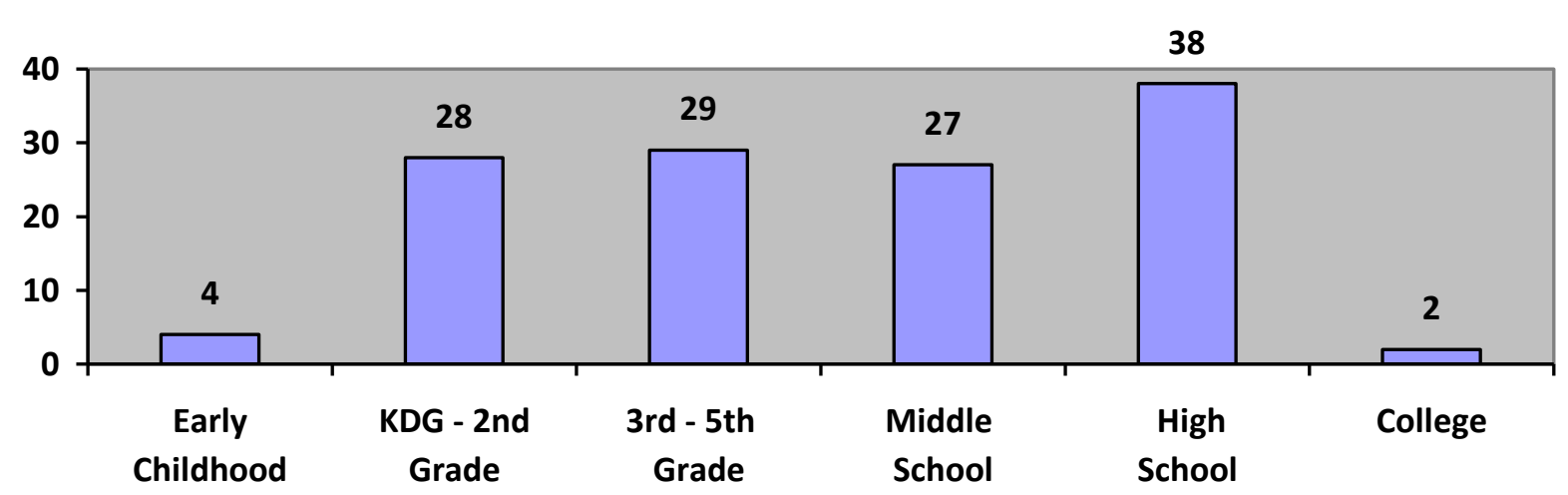

\section{Values-Based Decision Making}

Since the publication of A Nation at Risk in 1983, a continuous stream of reform efforts have challenged schools and teachers to improve. Professional development in education has been described as an organized effort to change teachers with the expected result of improving their teaching practice and student learning (Angelo 2001; 
Guskey, 1986). Yet, in spite of this prolonged effort, teaching and student performance have remained largely unchanged (National Staff Development Council, 2006).

What is needed is a new approach to teacher development that focuses on the needs of teachers, and is delivered in a meaningful way. Emerging efforts to link graduate teacher professional development to both practical and personal knowledge, as well as the more traditional discipline-based knowledge, reflects the natural convergence of constructivism and transformational learning (Nesbit, 2001).

According to Danielson (1996), "A framework for professional practice offers the profession a means of communicating about excellence...It is through serious, professional conversations about the components comprising the framework [for professional practice] that the components are validated for any particular setting" (p. 5). It is within such a framework that the program fosters a values-based decision making process that advances and facilitates an enriching progression of self-discovery and growth that examines individual attitudes, beliefs, values, and dispositions of effective teaching practices.

Most teachers are convinced that teaching skill is developed through classroom experience. Yet, there are limitations on the effectiveness of learning new and improved teaching skills from one's own experiences (Nutall, 2004). Organizational factors likely play a role in the resistance to significant operational change. The National Staff Development Council (2006) contends the lack of meaningful staff development and training ultimately produces teachers who revert to familiar past practices, perpetuating the status quo in teaching.

The educators who enroll in the program evolve into transformational educators, showcasing the foundational elements of effective teaching embedded into the learning community model. It is through this selfreflection process that beliefs, values, and attitudes centered on their teaching begin to become validated for them. As a professional, the integration of 'best practices', which encompasses lessons and activities designed to promote brain-based learning, differentiation, constructivism, and learning styles, sustains their ability to construct a support system designed to facilitate and cultivate partnerships in the learning arena.

Collaboration with colleagues, within and outside grade specific levels, for example, helps promote and showcases their integration of effective teaching strategies. This intentional structuring mechanism provides time for them to validate and, if needed, modify or completely change their teaching style. This assumes a metamorphic process, rather than demanding a drastic transformation, which could be more detrimental than assistive. It is not the intent to insist on wholesale change, but rather, and most importantly, this collaborative forum allows for a very direct and guided feedback system, which in turn will create an atmosphere that is not threatening or intimidating to those involved.

Table 1: Elements of Learning Community Philosophy

\begin{tabular}{lccc}
\hline Elements & Often & Almost Always & Total Percent \\
\hline $\begin{array}{l}\text { Dialogue with Other } \\
\text { Students }\end{array}$ & 31.0 & 68.0 & 99.0 \\
\hline $\begin{array}{l}\text { Collaborative } \\
\text { Problem Solving }\end{array}$ & 25.0 & 73.0 & 98.0 \\
\hline $\begin{array}{l}\text { Facilitator makes LC } \\
\text { emotionally safe }\end{array}$ & 15.0 & 83.0 & 98.0 \\
\hline $\begin{array}{l}\text { Provides many } \\
\text { Experiences/Activities }\end{array}$ & 26.0 & 72.0 & 98.0 \\
\hline $\begin{array}{l}\text { Facilitators Practice } \\
\text { Practices Advocated }\end{array}$ & 26.0 & 70.0 & 96.0 \\
\hline Note: Table reflects & & & \\
\hline
\end{tabular}

Note: Table reflects Often and Almost Always choices of a five-point Likert-type scale used: Almost Never, Seldom, Sometimes, Often, and Almost Always.

Regardless of the grade level or subject areas taught, educators have an opportunity to connect to 'best practices' and support each others' development in their own teaching. Whether a beginning or veteran teacher, the 
engagement levels focus on supporting current teaching practices, taking them from where they are and stretching them further, which brings a new level of practicality and realism to their classrooms and learning situations.

The basis for the learning community program lies in the theory of constructivism. At the end of their program, students are surveyed about the impact of the elements of the learning community philosophy. The data collected from students are provided in Table 1.

\section{Customized Involvement}

In examining teacher professional development, Guskey (2003) noted that research on the relationship between time and resources devoted to teacher professional development outcomes is mixed. What seems to be more important is the effectiveness in which professional development time is organized, structured, and directed.

Although incorporating common elements, each learning community is unique. Individually, each community will take on a customized approach to facilitate meeting the needs of its constituents. Through ongoing dialogue and use of groups referred to as Site Councils, for example, the ownership of the learning community clearly falls back to the group members, who represent and reflect the needs of the entire group, and thus, the accountability for each participating member is tied back to the group as a whole. The ability to 'slide under the radar' and avoid participating or not working to support the betterment of the group is not an acceptable practice.

The accountability to oneself, as well as the group, inherently provides opportunities to question and challenge one's own beliefs related to the functions and roles of individuals within the learning community, as well as the effectiveness of the small groups that evolved during the development of the learning community.

Norris, (et al., 2002) states,

In cohesive groups, individuals show respect for one another and a real appreciation and acknowledgment of their individual differences and contributions. A sense of security results within this environment that allows and promotes free exchange of ideas with no fear of retribution or disfavor. In such a setting, there is individual growth. Individuals receive mutual feedback in a safe environment, become more self-aware and develop greater knowledge through dialogue with others. p. 15

No one individual is above the group and no one group is bigger than the individual. Members of productive learning communities must be willing to accept feedback and work toward improvement which requires the respect and trust of colleagues (Hord, 2004). The collaborative roles students assume during discussions and projects linked to the program, such as lesson plans, artifacts for their portfolios, and their action research project affords them multiple opportunities to get involved in their own learning as well as creating a platform for them to enhance their individual skills and knowledge. They are intentionally provided time to make deliberate connections with each other, which helps establish and sustain a level of personal and professional learning and practice. As with any skill, team building and trust have to be practiced, supported, and learners need to feel safe before they will become a risk-taker.

As students receive validation and acceptance from each other, the facilitators must provide the guidance necessary to make the connections with each individual within the cohort. The collaborative efforts of the individuals and groups regularly engage a constant element of reflection. It is within this on-going reflective dialogue that learning community members begin to feel a sense of growth and accomplishment, both personally and professionally. As cited by Norris (et al., 2002), "Research indicates that learning is greatly enhanced in learning communities when students are provided opportunities to share ideas, elaborate on their own thoughts, and to consider the ideas of others" (Brubaker, 1994; Norris \& Barnett, 1994; Norris, Herrmond \& Meisgeier, 1996; Senge, 1990), p. 13.

Student survey data indicates the impact of the customized involvement elements (see Table 2). Three elements, which focus on their customized involvement within the learning community, are effective teaching strategies, best practices, and reflective practitioner. 
Table 2: Elements of Customized Involvement in Learning Communities

\begin{tabular}{lccc}
\hline Elements & Often & Almost Always & Total Percent \\
\hline Effective Teaching Strategies & 30.2 & 66.1 & 96.3 \\
\hline Best Practices & 30.2 & 65.9 & 96.1 \\
\hline Reflective Practitioner & 30.0 & 63.2 & 93.2 \\
\hline
\end{tabular}

Note: Table reflects Often and Almost Always choices of a five-point Likert-type scale used: Almost Never,

Seldom, Sometimes, Often, and Almost Always.

\section{Research-Based Evidence}

Research-supported evidence is validated throughout the program, in that, educators enrolled demonstrate a deeper understanding of how to best teach to meet the needs of their students. Characteristics of professional learning communities include supportive and shared leadership, shared values and vision, collective learning and application of learning, supportive conditions, and shared practice (Hord, 2004). In the learning communities, students are provided multiple opportunities to explore and research different teaching strategies; reflectively share their results/findings with other colleagues; are continuously engaged in a collaborative and collegial learning environment; and create a set of instructional improvements that support and enhance their development as a teacher leader.

The learning community program does more than just simply bring educators together. Rather, through deliberately collaborative and supportive engagement, educators process and interactively share with one another, this facilitates inquiry, reflection, scaffolding and professional growth. Thus, change occurs as they discuss, describe, and modify their practices (Little, 2003). According to a collectively held position of teacher quality, the process of learning with colleagues in small, trusting, supportive groups makes the difference (Dunne, Nave, and Lewis, 2000).

Current research suggests that providing intensive, content-rich, and collegial learning opportunities for teachers can improve both teaching and student learning (Darling-Hammond \& Richardson, 2009). This model is structured in such a way as to initiate professional growth and development by allowing educators to practice with new information, engage in collaborative sharing, and create opportunities to support their learning environments through the elements of the program.

Student survey data represent the impact of elements of research based practices in the learning communities (see Table 3).

Table 3: Elements of Research-based Practices in Learning Communities

\begin{tabular}{llcc}
\hline Elements & Often & Almost Always & Total Percent \\
\hline Effective Teaching Strategies & 30.2 & 66.1 & 96.3 \\
\hline Best Practices & 30.2 & 65.9 & 96.1 \\
\hline Scaffolding & 32.5 & 63.6 & 96.1 \\
\hline Professional Growth & 30.5 & 63.0 & 93.5 \\
\hline Reflective Practitioner & 30.0 & 63.2 & 93.2 \\
\hline Inquiry & 34.9 & 58.1 & 93.0 \\
\hline Note:
\end{tabular}

Note: Table reflects Often and Almost Always choices of a five-point Likert-type scale used: Almost Never,

Seldom, Sometimes, Often, and Almost Always.

\section{Collaboration}

The collaborative curriculum that has been designed is more than just a one-time exposure to content and information. The intentional structure of the program provides ongoing opportunities to practice, reflect, and improve instruction through a spiraling approach of delivery. Professional development in education should be viewed as a process of transformation through critical reflection, with the goal of achieving a greater capacity to think and act differently (Kerka, 2003). 
The transformational interactions that result from their participation in the program help inspire and empower teachers and invigorate learning and teaching. It is through this collaboration and building of community that educators are engaged and begin to explore an approach to empowerment and transformational practices that support best teaching practices, encourages them to try new approaches, and gives them continuous opportunities to reflect, process, and examine their own growth as an educator. Transformational learning acknowledges that one's beliefs, values, and assumptions provide the perspective through which meaning of experience is formed. When this system of understanding is found to be inadequate for new and changing experiences, transformational learning can provide a new perspective. The newly adapted perspective is more refined and reflective, and leads to increasing capacity for learning and growth (Mezirow, 2000).

Three elements of teaching practices were surveyed throughout the two year program. The summative results, which included best practices, effective teaching strategies, and reflective practitioner, demonstrates the impact the program had on the students' growth and development (See Table 4).

Table 4: Elements of Collaboration Fostered in Learning Communities

\begin{tabular}{llll}
\hline Elements & Often & Almost Always & Total Percent \\
\hline $\begin{array}{l}\text { Opportunities for others } \\
\text { to explain ideas }\end{array}$ & 29.0 & 70.0 & 99.0 \\
\hline $\begin{array}{l}\text { Opportunities to dialogue } \\
\text { with others }\end{array}$ & 31.0 & 68.0 & 99.0 \\
\hline Breaks down teacher isolation & 34.0 & 65.0 & 99.0 \\
\hline $\begin{array}{l}\text { Focuses on collaborative } \\
\text { problem solving }\end{array}$ & 25.0 & 73.0 & 98.0 \\
\hline $\begin{array}{l}\text { Emphasizes professional } \\
\text { Scholarship }\end{array}$ & 31.0 & 66.0 & 97.0 \\
\hline $\begin{array}{l}\text { Enhanced importance of strong } \\
\text { interpersonal relationships }\end{array}$ & 31.0 & 66.0 & 97.0 \\
\hline Freedom to express opinions & 19.0 & 76.0 & 95.0 \\
\hline Part of a larger change process & 38.0 & 55.0 & 93.0 \\
\hline $\begin{array}{l}\text { Learn leadership skills to } \\
\text { initiate change }\end{array}$ & 44.0 & 49.0 & 93.0 \\
\hline $\begin{array}{l}\text { Increased school/community } \\
\text { Involvement }\end{array}$ & 21.0 & 68.0 & 89.0 \\
\hline Note: Table rlects Often and Almost & Always & & \\
\hline
\end{tabular}

Note: Table reflects Often and Almost Always choices of a five-point Likert-type scale used: Almost Never, Seldom, Sometimes, Often, and Almost Always.

\section{Creating Teacher Leaders}

Through the framework established within the delivery model, educators who enroll in the program experience several foundational elements that facilitate their personal and professional growth. This increased capacity for learning, growth, and development enhances students' abilities to reconstruct and transform themselves as educational leaders. The goal of the program is to create conditions that lead to significant change in the teachers' values, beliefs, and actions as a professional educator. This is in contrast to the in-service training and workshops attended by educators, which seldom result in more than a shallow or temporary change in knowledge.

Student surveys reported the impact of the elements of leadership fostered in the learning communities (See Table 5). 
Table 5: Elements of Leadership Fostered in Learning Communities

\begin{tabular}{lccl}
\hline Elements & Often & Almost Always & Total Percent \\
\hline $\begin{array}{l}\text { Research-Based } \\
\text { Decision Making }\end{array}$ & 31.5 & 64.9 & 96.4 \\
\hline Empowerment & 30.7 & 62.8 & 93.5 \\
\hline Change Agent & 31.7 & 60.5 & 92.2 \\
\hline
\end{tabular}

Note: Table reflects Often and Almost Always choices of a five-point Likert-type scale used: Almost Never, Seldom, Sometimes, Often, and Almost Always.

Twelve central elements have been directly linked to the survey instruments used. The consistently high scores of above 92.5 percent gathered from student surveys over a 5 year period clearly demonstrate the effectiveness and impact of the learning community model.

\section{AUTHOR INFORMATION}

Dr. Sharon E. Kabes, Associate Professor, is former Chair of the Department of Education at Southwest Minnesota State University. She is a member of the graduate faculty and has been a facilitator in the Master of Science Education Learning Community program for seven years.

Dr. Dennis Lamb, Associate Professor of Education, Southwest Minnesota State University, is a member of the graduate faculty and has been a facilitator in the Master of Science Education Learning Community program for three years. He also served as coordinator of an off-campus degree completion program in elementary education with SMSU for five years, prior to joining the graduate program.

Dr. John Engstrom is an Assistant Professor at Southwest Minnesota State University where he is a member of the graduate faculty. He was among the first graduates of the learning community program, and has facilitated learning communities since 1998.

\section{REFERENCES}

1. Angelo, T. (2001). Doing faculty development as if we value learning most: Transformative guidelines from research to practice. To Improve the Academy, 19, 97-112. Bolton, MA: Anker Publishing.

2. Cunningham, W.G. \& Cordeiro, P.A. (2009). Educational leadership: A bridge to improved practice. $4^{\text {th }}$ ed. Boston: Pearson.

3. Danielson, C. (1996). Enhancing professional practice: A framework for teaching. Alexandria, VA: ASCD.

4. Darling-Hammond, L. \& Richardson, N. (2009). Teacher learning: What matters? Educational Leadership, 66(5), 46-55.

5. Dunne, F., Nave, B., \& Lewis, A. (2000). Critical friends: Teachers helping to improve student learning. Phi Delta Kappa International Research Bulletin (CEDR) (28), 9-12. www.pdkintl.org/edres/resbul28.htm.

6. Guskey, T. R. (June, 2003). What makes professional development effective? Phi Delta Kappan 84(10), 748-750.

7. Guskey, T. (1986). Staff development and the process of teacher change. Educational Researcher, 15(5), 512.

8. Hord, S.M. (2004). Learning together leading together: Changing schools through professional learning communities. New York: Teachers College Press.

9. Kerka, S. (2003). Does adult educator professional development make a difference? Myths and realities. ERIC Clearinghouse on Adult, Career, and Vocational Education. (ED482331)

10. Kriete, R. (2003). Start the day with community. Educational Leadership, 61(1), 68-71.

11. Little, J.W. (2003). Inside teacher community: Representations of classroom practice. Teachers College Record: 105(6), 913-945.

12. Mezirow, J. (2000). Learning as transformation: Critical perspectives on a theory in progress. San Francisco: Jossey-Bass. 
13. National Staff Development Council (2006). What a school leader needs to know: Meeting basics. The Learning Principal, 1(6) 4.

14. Nesbit, T. (2001). Extending graduate education to non-traditional learners. Journal of Continuing Higher Education, 49(1), 2-10.

15. Nieto, S. (2009). From surviving to thriving. Educational Leadership, 66(5), 8 - 13.

16. Nuthall, G. (2004). Relating classroom teaching to student learning: A critical analysis of why research has failed to bridge the theory-practice gap. Harvard Educational Review, 74(3), 273-306. 
NOTES 